\title{
PERSEPSI DOKTER MUDA DALAM MENGHADAPI WABAH CORONAVIRUS DISEASE (COVID-19) DI BLUD RUMAH SAKIT CUT MEUTIA TAHUN 2020
}

\author{
Harvina Sawitri ${ }^{1}$, Nora Maulina ${ }^{2}$ \\ ${ }^{1}$ Bagian Ilmu Kesehatan Masyarakat, Fakultas Kedokteran, Universitas Malikussaleh \\ ${ }^{2}$ Bagian Fisiologi, Fakultas Kedokteran, Universitas Malikussaleh \\ Corresponding Author : nora.maulina@unimal.ac.id
}

\begin{abstract}
Abstrak
Coronavirus merupakan keluarga besar virus yang menyebabkan penyakit ringan sampai berat, seperti common cold atau pilek dan penyakit yang serius seperti MERS dan SARS. Gejalanya demam, batuk, dan sesak napas yang membutuhkan perawatan di RS. Orang yang lebih tua dan memiliki masalah medis mendasar seperti penyakit kardiovaskular, diabetes, penyakit pernapasan kronis, dan kanker lebih berisiko untuk mengalami penyakit yang serius. Kasus coronavirus pertama kali ditemukan di Cina. Setelah itu, dalam beberapa minggu, virus ini menyebar ke seluruh bagian negara Cina dan dalam kurun waktu 1 bulan menyebar ke negara lainnya, termasuk Italia, Amerika Serikat, dan Jerman hingga ke Asia. Kematian akibat virus ini telah mencapai 580.045 kasus. Tingkat kematian akibat penyakit ini mencapai 4-5\% dengan kematian terbanyak terjadi pada kelompok usia di atas 65 tahun. Tenaga medis berperan penting menolong pasien di rumah sakit, klinik dan tempat medis lainnya. Semua tenaga medis termasuk dokter, perawat dan bidan serta dokter muda akan mengorbankan waktu, pikiran dan tenaga untuk memerangi penyebaran virus. Seluruh tenaga medis dari berbagai profesi dan kelompok yang terlibat dalam merawat pasien akan sangat mudah tertular coronavirus. Penelitian ini bertujuan mengetahui Persepsi (termasuk pengetahuan dan sikap) dokter muda dalam menghadapi wabah Coronavirus. Penelitian dilakukan di Rumah Sakit Cut Meutia pada tahun 2020 dengan menggunakan rancangan penelitian Cross-Sectional dan metode sampling Purposive Sampling. Hasil penelitian menunjukkan sebagian besar dokter muda mempunyai pengetahuan yang baik (67\%), sikap yang baik (68\%) dan persepsi yang baik $(72 \%)$ dalam menghadapi pandemi COVID-19 ditempat pendidikannya. Namun masih banyak persepsi yang salah tentang virus COVID-19 seperti masih terpengaruh dengan postingan media sosial $(54,7 \%)$, terpengaruh dengan perbincangan pandemi virus Corona di media massa $(50,7 \%)$ dan $34,7 \%$ menganggap anda virus COVID-19 adalah senjata biologi.
\end{abstract}

Kata Kunci : persepsi-dokter-muda, COVID-19, pandemic

\section{Perceptions Of Young Doctors In Facing The Coronavirus Disease (Covid-19) Outbreak At Cut Meutia Hospital Blud In 2020}

\begin{abstract}
Coronavirus is a large family of viruses that cause mild to severe illness, such as the common cold or the common cold and serious diseases such as MERS and SARS. Symptoms include fever, cough, and shortness of breath that require hospitalization. People who are older and have underlying medical problems such as cardiovascular disease, diabetes, chronic respiratory disease, and cancer are more at risk for serious illness. The first case of coronavirus was
\end{abstract}


discovered in China. After that, within a few weeks, this virus spread to all parts of China and within 1 month it spread to other countries, including Italy, the United States, and Germany to Asia. Deaths from this virus have reached 580,045 cases. The death rate from this disease reaches $4-5 \%$ with the most deaths occurring in the age group over 65 years. Medical personnel play an important role in helping patients in hospitals, clinics and other medical places. All medical personnel including doctors, nurses and midwives as well as young doctors will sacrifice time, thought and energy to fight the spread of the virus. All medical personnel from various professions and groups involved in treating patients will be very easily infected with the coronavirus. This study aims to determine the perceptions (including knowledge and attitudes) of young doctors in dealing with the Coronavirus outbreak. The study was conducted at Cut Meutia Hospital in 2020 using a cross-sectional research design and purposive sampling method. The results showed that most of the young doctors had good knowledge $(67 \%)$, good attitude $(68 \%)$ and good perception (72\%) in dealing with the COVID-19 pandemic in their place of education. However, there are still many wrong perceptions about the COVID-19 virus, such as being influenced by social media posts $(54.7 \%)$, being influenced by conversations about the Corona virus pandemic in the mass media (50.7\%) and 34.7\% assuming you are a COVID-19 virus. 19 is a biological weapon.

Keywords: young-doctor perception, COVID-19, pandemic

\section{PENDAHULUAN}

Coronavirus merupakan keluarga besar virus yang menyebabkan penyakit ringan sampai berat, seperti common cold atau pilek dan penyakit yang serius seperti MERS dan SARS. Gejalanya demam $>38^{\circ} \mathrm{C}$, batuk, sesak napas yang membutuhkan perawatan di RS. Gejala ini diperberat jika penderita adalah usia lanjut dan mempunyai penyakit penyerta lainnya, seperti penyakit paru obstruktif menahun atau penyakit jantung (1). Orang yang lebih tua dan memiliki masalah medis mendasar seperti penyakit kardiovaskular, diabetes, penyakit pernapasan kronis, dan kanker lebih berisiko untuk mengalami penyakit yang serius (2).

Kasus coronavirus pertama kali ditemukan di Cina. Setelah itu, dalam beberapa minggu, virus ini menyebar ke seluruh bagian negara Cina dan dalam kurun waktu 1 bulan menyebar ke negara lainnya, termasuk Italia, Amerika Serikat, dan Jerman. Sampai tanggal 30 April 2020, Coronavirus sudah ditemukan di 213 negara (3). Hingga 17 Juli 2020, jumlah kasus infeksi COVID-19 terkonfirmasi mencapai 13.378.853 kasus. Awalnya kasus terbanyak terdapat di Cina, namun saat ini kasus terbanyak terdapat di Amerika dengan 7.016.851 kasus, diikut oleh Eropa dengan 2.987.256 kasus dan Mediterania 1.331.893 kasus. Kematian akibat virus ini telah mencapai 580.045 kasus. Tingkat kematian akibat penyakit ini mencapai 4-5\% dengan kematian terbanyak terjadi pada kelompok usia di atas 65 tahun (4). 
Indonesia melaporkan kasus pertama pada 2 Maret 2020, yang diduga tertular dari orang asing yang berkunjung ke Indonesia (5). Kasus di Indonesia pun terus bertambah, hingga tanggal 16 Juli 2020 telah terdapat 81.668 kasus dengan kematian mencapai 3.873 jiwa. Tingkat kematian Indonesia 5\%, termasuk angka kematian tertinggi (6). Berdasarkan data yang ada, umur pasien yang terinfeksi COVID-19 mulai dari usia 30 hari hingga 89 tahun. Menurut laporan 138 kasus di Kota Wuhan, didapatkan rentang usia 37-78 tahun dengan rerata 56 tahun (42-68 tahun) tetapi pasien rawat ICU lebih tua (median 66 tahun (57-78 tahun) dibandingkan rawat non-ICU (37-62 tahun) dan 54,3\% laki-laki. Laporan 13 pasien terkonfirmasi COVID-19 di luar Kota Wuhan menunjukkan umur lebih muda dengan median 34 tahun (34-48 tahun) dan 77\% laki-laki (5).

Tenaga medis berperan penting menolong pasien di rumah sakit, klinik dan tempat medis lainnya. Semua tenaga medis termasuk dokter, perawat dan bidan serta dokter muda akan mengorbankan waktu, pikiran dan tenaga untuk memerangi penyebaran Covid-19. Adapun tugastugas pokok dokter muda yaitu belajar (melihat banyak kasus secara langsung banyak mendiskusikan kasus tersebut) dan berinteraksi langsung dengan pasien (7). Seluruh tenaga medis dari berbagai profesi dan kelompok yang terlibat dalam merawat pasien akan sangat mudah tertular coronavirus. Literatur menunjukkan bahwa kurangnya pengetahuan dan kurangnya pemahaman yang baik di antara petugas kesehatan menyebabkan diagnosis tertunda, mudahnya penyebaran penyakit dan praktik pengendalian infeksi yang buruk. Ribuan petugas medis di Rumah Sakit di Tiongkok terjangkit coronavirus saat awal pandemi, sehingga penularan di Rumah sakit harus menjadi prioritas. Pengetahuan, sikap dan survei praktik adalah cara yang cocok untuk mengevaluasi program yang ada dan untuk mengidentifikasi strategi yang efektif untuk perubahan perilaku pada tenaga medis . Penelitian di Pakistan tahun 2020 menunjukkan bahwa pengetahuan tenaga medis terhadap penularan penyakit infeksi coronavirus hanya $40 \%$ (rendah) (8). Hasil penelitian yang sama juga ditunjukkan oleh survei yang dilakukan di Uni Emirat Arab (2020) dimana respondennya adalah 30\% dokter dan 29\% dokter muda mempunyai pengetahuan yang buruk tentang onset penyakit dan penyebaran virus (9).

\section{METODE PENELITIAN}

Penelitian akan dilakukan di Rumah Sakit Umum Cut Meutia Kabupaten Aceh Utara. Variabel dalam penelitian ini adalah pengetahuan, sikap dan persepsi dokter muda terhadap wabah coronavirus. Rancangan penelitian ini adalah penelitian deskriptif dengan rancangan potong 
lintang (juga dikenal sebagai analisis cross-sectional, studi transversal, studi prevalensi ) adalah jenis studi observasional yang menganalisis data dari suatu populasi, atau bagian yang representatif, di titik waktu tertentu — yaitu, data cross-sectional. Analisis data yang dilakukan menggunakan analisis statistik deskriptif dengan menyajikan data dalam bentuk tabel dan grafik.

\section{HASIL DAN PEMBAHASAN}

\section{Hasil Penelitian}

Total responden yang mengisi kuesioner adalah 75 orang. Pertanyaan kuesioner dibagi menjadi tiga bagian yaitu pengetahuan, sikap dan persepsi dokter muda dalam menghadapi Coronavirus di rumah sakit tempatnya bertugas. Berikut adalah hasil penelitian yang diperoleh.

\section{A. Gambaran Pengetahuan Dokter Muda dalam menghadapi Coronavirus (COVID-19)}

Berdasarkan respon kuesioner yang dapat dilihat pada Gambar 5.1, sebagian besar dokter muda mempunyai pengetahuan yang baik (67\%), dengan distribusi pertanyaan yang tercakup dalam tabel 5.1. Dari distribusi pertanyaan, dapat diketahui bahwa rata-rata pengetahuan tentang definisi, gejala penyakit dan pencegahan sudah baik. Namun pada pertanyaan tentang coronavirus dapat diatasi dengan antibiotik biasa (37,3\%) dan pertanyaan mengenai virus Corona dapat menular melalui udara terbuka $(38,7 \%)$ masih banyak yang menjawab salah.

Tabel 1 Gambaran Distribusi Pertanyaan tentang Pengetahuan Dokter Muda dalam menghadapi Coronavirus (COVID-19) di BLUD Cut Meutia Tahun 2020

\begin{tabular}{llcccc}
\hline No & \multicolumn{1}{c}{ Pertanyaan } & \multicolumn{2}{c}{ Jawaban Benar } & \multicolumn{2}{c}{ Jawaban Salah } \\
& & $\mathbf{n}$ & $\mathbf{\%}$ & $\mathbf{n}$ & $\mathbf{\%}$ \\
\hline 1 & $\begin{array}{l}\text { COVID-19 adalah infeksi saluran pernapasan yang } \\
\text { disebabkan oleh spesies baru dari famili virus corona }\end{array}$ & 73 & 97,3 & 2 & 2,7 \\
$2 \quad$ & $\begin{array}{l}\text { Asal muasal COVID-19 tidak jelas tetapi tampaknya } \\
\text { ditularkan ke manusia melalui makanan laut, ular, atau } \\
\text { kelelawar }\end{array}$ & 60 & 80 & 15 & 20 \\
$3 \quad \begin{array}{l}\text { Gejala COVID-19 umumnya adalah demam, batuk, } \\
\text { dan sesak napas tetapi mual dan diare jarang } \\
\text { dilaporkan }\end{array}$ & 70 & 93,3 & 5 & 6,7 \\
COVID-19 dapat diatasi dengan pemberian antibiotic & 47 & 62,7 & 28 & 37,3 \\
\hline
\end{tabular}




\begin{tabular}{|c|c|c|c|c|c|}
\hline & dan antivirus biasa & & & & \\
\hline 5 & $\begin{array}{l}\text { COVID-19 ditularkan melalui buah-buahan yang } \\
\text { diimpor dari luar negeri }\end{array}$ & 67 & 89,3 & 8 & 10,7 \\
\hline 6 & $\begin{array}{l}\text { COVID-19 Menular melalui kontak dekat dengan } \\
\text { kasus yang terinfeksi (terutama di keluarga, tempat } \\
\text { keramaian dan puskesmas) }\end{array}$ & 74 & 98,7 & 1 & 1,3 \\
\hline 7 & $\begin{array}{l}\text { Masker kesehatan berguna untuk mencegah } \\
\text { penyebaran seperti saat batuk dan bersin }\end{array}$ & 75 & 100 & 0 & 0 \\
\hline 8 & $\begin{array}{l}\text { Penyakit ini dapat dicegah dengan tidak melakukan } \\
\text { kontak dekat seperti jabat tangan atau berciuman, } \\
\text { tidak menghadiri rapat dan sering melakukan tangan } \\
\text { disinfeksi }\end{array}$ & 74 & 98.7 & 1 & 1.3 \\
\hline 9 & Semua orang di masyarakat harus memakai masker & 74 & 98,7 & 1 & 1,3 \\
\hline 10 & $\begin{array}{l}\text { Virus COVID-19 dapat menular melalui udara } \\
\text { diruangan terbuka }\end{array}$ & 46 & 61,3 & 29 & 38,7 \\
\hline
\end{tabular}

\section{Pengetahuan Dokter Muda dalam \\ Menghadapi COVID-19}

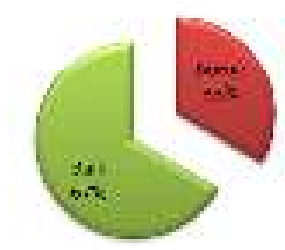

\section{Gambar 1 Pengetahuan Dokter Muda dalam Menghadapi COVID-19}

\section{B. Gambaran Sikap Dokter Muda dalam menghadapi Coronavirus (COVID-19)}

Berdasarkan respon kuesioner yang dapat dilihat pada Gambar 5.2, sebagian besar dokter muda mempunyai sikap yang baik (68\%), dengan distribusi pertanyaan yang tercakup dalam tabel 5.2. Dari distribusi pertanyaan, dapat diketahui bahwa sikap dokter muda dalam menghadapi pandemi sebagian besar sudah baik, namun masih banyak dokter muda (30,7\%) yang belum yakin dengan alat diagnosa yang ditetapkan oleh pemerintah dan sebanyak $40 \%$ dokter muda tidak yakin dengan peraturan yang diterapkan oleh pemerintah untuk mengatasi COVID-19.

Tabel 2 Gambaran Distribusi Pertanyaan tentang Sikap Dokter Muda dalam menghadapi Coronavirus (COVID-19) di BLUD Cut Meutia Tahun 2020 


\begin{tabular}{|c|c|c|c|c|c|}
\hline \multirow[t]{2}{*}{ No } & \multirow[t]{2}{*}{ Pertanyaan } & \multicolumn{2}{|c|}{ Jawaban Positif } & \multicolumn{2}{|c|}{ Jawaban Negatif } \\
\hline & & $\mathbf{n}$ & $\%$ & n & $\%$ \\
\hline 1 & $\begin{array}{l}\text { Selama masa pandemi, saya membatalkan atau } \\
\text { menunda pertemuan dengan teman, makan di luar dan } \\
\text { acara olahraga }\end{array}$ & 75 & 100 & 0 & 0 \\
\hline 2 & $\begin{array}{l}\text { Selama masa pandemi saya mengurangi penggunaan } \\
\text { transportasi umum }\end{array}$ & 75 & 100 & 0 & 0 \\
\hline 3 & Selama masa pandemi saya lebih jarang berbelanja & 70 & 93,3 & 5 & 6,7 \\
\hline 4 & $\begin{array}{l}\text { Selama masa pandemi saya mengurangi penggunaan } \\
\text { ruang tertutup, seperti perpustakaan, teater, dan bioskop }\end{array}$ & 75 & 100 & 0 & 0 \\
\hline 5 & $\begin{array}{l}\text { Selama masa pandemi saya meningkatkan frekuensi } \\
\text { pembersihan dan desinfektan item yang dapat dengan } \\
\text { mudah disentuh dengan tangan (misalnya gagang pintu } \\
\text { dan permukaannya) }\end{array}$ & 73 & 97,3 & 2 & 2,7 \\
\hline 6 & $\begin{array}{l}\text { Selama masa pandemi saya tidak membahas } \\
\text { pencegahan COVID-19 dengan keluarga dan teman } \\
\text { saya }\end{array}$ & 6 & 8 & 69 & 92 \\
\hline 7 & $\begin{array}{l}\text { Saya yakin apabila kita menjalankan Perilaku Hidup } \\
\text { Bersih Sehat maka kita tidak akan terinfeksi COVID-19 }\end{array}$ & 70 & 93,3 & 5 & 6,7 \\
\hline 8 & $\begin{array}{l}\text { Saya belum yakin dengan diagnosis COVID-19 } \\
\text { menggunakan alat diagnostik yang telah ditetapkan } \\
\text { oleh pemerintah saat ini }\end{array}$ & 23 & 30,7 & 52 & 69,3 \\
\hline 9 & $\begin{array}{l}\text { Saya yakin bahwa rumah sakit di tempat saya } \\
\text { menjalankan pendidikan telah menerapkan prosedur } \\
\text { pencegahan COVID-19 dengan baik }\end{array}$ & 59 & 78,7 & 16 & 21,3 \\
\hline 10 & $\begin{array}{l}\text { Saya tidak yakin dengan peraturan yang diterapkan } \\
\text { oleh pemerintah untuk mengatasi COVID-19 }\end{array}$ & 30 & 40 & 45 & 60 \\
\hline
\end{tabular}

\section{Bikap Dodates BAda datom}

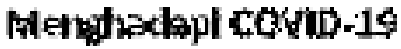

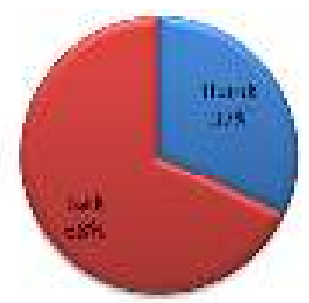

Gambar 5.2 Sikap Dokter dalam Menghadapi COVID-19

\section{Gambaran Persepsi Dokter Muda dalam menghadapi Coronavirus (COVID-19)}

Berdasarkan respon kuesioner yang dapat dilihat pada Gambar 5.3, sebagian besar dokter muda mempunyai persepsi yang baik (72\%), dengan distribusi pertanyaan yang tercakup dalam tabel 5.3. Dari distribusi pertanyaan, dapat diketahui bahwa persepsi dokter muda mengenai dampak virus corona dan kesehatan mental saat pandemi sudah baik. Namun, masih banyak dokter muda menganggap media terlalu melebih-lebihkan kasus COVID-19 (53,3\%), masih 
terpengaruh dengan postingan media sosial (54,7\%), terpengaruh dengan perbincangan Pandemi Virus Corona di Koran dan kanal berita (50,7\%) dan 34,7 \% menganggap anda virus COVID-19 adalah senjata biologi.

Tabel 3 Gambaran Distribusi Pertanyaan tentang Persepsi Dokter Muda dalam menghadapi Coronavirus (COVID-19) di BLUD Cut Meutia Tahun 2020

\begin{tabular}{|c|c|c|c|c|c|}
\hline \multirow[t]{2}{*}{ No } & \multirow[t]{2}{*}{ Pertanyaan } & \multicolumn{2}{|c|}{ Jawaban Ya } & \multicolumn{2}{|c|}{ Jawaban Tidak } \\
\hline & & $\mathbf{n}$ & $\%$ & n & $\%$ \\
\hline 1 & $\begin{array}{l}\text { Apakah menurut anda, corona virus dapat } \\
\text { menyebabkan kematian }\end{array}$ & 69 & 92 & 6 & 8 \\
\hline 2 & $\begin{array}{l}\text { Apakah menurut anda, media terlalu melebih-lebihkan } \\
\text { kasus COVID-19 dan berperan dalam propaganda isu }\end{array}$ & 40 & 53,3 & 35 & 46,7 \\
\hline 3 & $\begin{array}{l}\text { Apakah menurut Anda akan menyenangkan untuk } \\
\text { berbicara dengan seseorang tentang kekhawatiran Anda } \\
\text { akan epidemi virus COVID 19? }\end{array}$ & 50 & 66,7 & 25 & 33,3 \\
\hline 4 & $\begin{array}{l}\text { Menurut Anda, apakah perlu mendapatkan bantuan } \\
\text { kesehatan mental jika seseorang panik karena situasi } \\
\text { Pandemi? }\end{array}$ & 74 & 98,7 & 1 & 1,3 \\
\hline 5 & $\begin{array}{l}\text { Menurut Anda, apakah akan bermanfaat jika ahli } \\
\text { kesehatan mental membantu orang dalam menghadapi } \\
\text { saat situasi pandemi COVID19? }\end{array}$ & 71 & 94,7 & 4 & 5,3 \\
\hline 6 & $\begin{array}{l}\text { Apakah Anda akan menyarankan orang untuk } \\
\text { mendapatkan bantuan kesehatan mental kepada orang } \\
\text { yang sangat terpengaruh oleh pandemi COVID19? }\end{array}$ & 68 & 90,7 & 7 & 9,3 \\
\hline 7 & $\begin{array}{l}\text { Sejak seminggu terakhir, apakah anda merasa } \\
\text { terpengaruh oleh postingan di media sosial tentang } \\
\text { infeksi Virus Corona? }\end{array}$ & 41 & 54,7 & 34 & 45,3 \\
\hline 8 & $\begin{array}{l}\text { Sepekan terakhir ini, apakah anda merasa terpengaruh } \\
\text { dengan perbincangan Pandemi Virus Corona di Koran } \\
\text { dan kanal berita? }\end{array}$ & 38 & 50,7 & 37 & 49,3 \\
\hline 9 & $\begin{array}{l}\text { Apakah menurut anda, keluarga anda berisiko untuk } \\
\text { terinfeksi COVID-19 }\end{array}$ & 55 & 73,3 & 20 & 26,7 \\
\hline 10 & $\begin{array}{l}\text { Apakah menurut anda virus COVID-19 adalah senjata } \\
\text { biologi }\end{array}$ & 26 & 34,7 & 49 & 65,3 \\
\hline
\end{tabular}

Persepsi Dokter Muda dalam

Menghadapi COVID-19

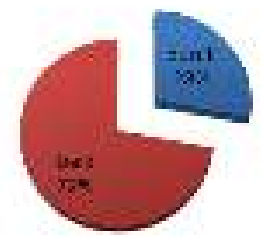

Gambar 5.3 Persepsi Dokter Muda dalam Menghadapi COVID-19

\section{Pembahasan}




\section{A. Pengetahuan Dokter Muda dalam Menghadapi COVID-19}

Berdasarkan hasil penelitian, $67 \%$ dokter muda berpengetahuan baik dalam menjawab kuisioner. Berdasarkan hasil riwayat peserta penelitian beserta kategori kasus masyarakat di masa pandemi COVID-19, menunjukkan persepsi dokter muda di Rumah Sakit Umum Cut Mutia Lhokseumawe memiliki risiko rendah untuk terpapar infeksi virus SARS-CoV-2 sebagai penyebab kasus COVID-19. Dalam proses kontak langsung, maka orang sehat secara tidak sengaja menyentuh orang terinfeksi virus SARS-CoV2, ataupun orang tersebut menyentuh permukaan dan peralatan yang disentuh orang terinfeksi virus SARS-CoV-2. Secara umum, permukaan dan peralatan tersebut telah terkontaminasi oleh droplet berukuran besar yang berisi virus SARS-CoV-2 dari pasien COVID-19, dimana virus tersebut dapat tetap stabil dalam jangka waktu tertentu (10). Peristiwa-peristiwa tersebut dapat mendukung masuknya virus SARS-CoV2 ke dalam tubuh orang yang sehat dan proses infeksi akan berlanjut. Hasil penelitian ini didukung penelitian pengetahuan mahasiswa Cina terkait dengan Covid-19 dengan hasil pengetahuan $82,3 \%$ baik (11). Data pengetahuan mahasiswa di Pakistan terkait dengan pengetahuan dalam pencegahan Covid 19 mempunyai pengetahuan yang bagus (12). Penelitian berbanding terbalik dengan pengetahuan mahasiswa di salah satu universitas Bangladesh, hasil penelitian menunjukkan pengetahuan mahasiswa sebagian besar buruk (13), hal ini serupa dengan data pengetahuan mahasiswa kedokteran di India yang memiliki pengetahuan buruk terkait dengan Covid-19 (14). Berbeda dengan hasil penelitain pada siswa di Filipina didapatkan pengetahuan terkait dengan pencegahan covid-19 dengan hasil pengetahuan cukup (15).

Pengetahuan sangat penting dalam mendasari terbentuknya tindakan karena suatu prilaku dibentuk dari pengetahuan sehingga pengetahuan baru akan menimbulkan tanggapan batin dalam bentuk sikap dan akan timbul tanggapan lebih jauh berupa tindakan. Pengetahuan yang baik tentang pengendalian infeksi yang dimiliki mahasiswa profesi dokter dapat menentukan tindakan yang tepat dalam upaya pencegah dan pengendalian infeksi (16). Salah satu yang menjadi penyebab utama pengetahuan yang buruk adalah karena keterbatasan akses untuk mendapatkan informas kemudian masih adanya sebagian penduduk yang mengalami buta huruf, banyaknya lansia di pedesaan akan lebih berisiko memiliki pengetahuan yang buruk dalam pencegahan Covid-19 (12) . Informasi Covid-19 didapatkan mahasiswa dari media social, internet, televisi, kementrian kesehatan, WHO dan informasi teman (17). Hingga saat ini artikel ini ditulis 
pemerintah Indonesia bersama kementrian kesehatan melakukan tindakan-tindakan signifikan pemberian informasi guna peningkatan pengetahuan terkait dengan edukasi pencegahan penularan virus Covid-19 dan bahaya Covid-19 pada masyarakat melalui media social, televisi surat kabar. Pemerintah memberikan edukasi pada masyarakat terkait protokol kesehatan saat bertemu dengan orang lain seperti selalu memakai masker, menjaga jarak minimal 1 meter, dan selalu cuci tangan menggunakan sabun (18). Pengetahuan yang baik, akan mendorong sikap positif (11).

\section{B. Sikap Dokter Muda dalam Menghadapi COVID-19}

Menurut Notoadmodjo, sikap merupakan reaksi atau respon yang masih tertutup dari seseorang terhadap suatu stimulus atau objek. Manifestasi sikap tidak dapat dilihat langsung tetapi hanya dapat ditafsirkan terlebih dahulu dari perilaku yang tertutup. Sikap secara nyata menunjukkan konotasi adanya kesesuaian reaksi terhadap stimulus tertentu yang dalam kehidupan sehari-hari merupakan reaksi yang bersifat emosional terhadap stimulus sosial (19). Hasil penelitian distribusi frekuensi berdasarkan sikap mahasiswa Kesehatan dalam melakukan pencegahan Covid-19 di Indonesia didapatkan prosentase sikap paling tinggi berada di kategori sikap baik. Hal ini sejalan dengan sikap dokter muda UNIMAL dalam bersikap baik dalam upaya pencegahan Covid-19 Didukung penelitian sikap siswa di Pakistan didapatkan sikap yang baik (12), di India mempunyai sikap yang baik dalam pencegahan covid-19 pada mahasiswa kedokteran (20) dan penelitian pada mahasiswa di Cina didapatkan sikap yang positif pada dalam pencegahan covid-19 (11). Berbeda dengan hasil di Uganda dimana responden adalah sopir, pengusaha dan pekerja keamanan memiliki sikap lebih buruk (21).

Sikap mahasiswa Indonesia dalam penelitian ini ditunjukkan dalam mencuci tangan menggunakan sabun dan antiseptik, menghindari kontak langsung dengan orang, menggunakan masker, menerapkan etika batuk dan bersin . Sikap positif juga dilakukan siswa di Philipina dalam pencegahan covid-19 dengan cara memakai masker, mencuci tangan dengan sabun, tetap tinggal dirumah, menghindari kerumunan dan menghindari kontak fisik antar sesama (15). Sikap positif juga dilakukan mahasiswa di Jordan seperti mencuci tangan dengan handsanitiser, menggunakan masker dapat meminimalkan penularan penyakit dan mengikuti etika ketika batuk dan bersin. Pemerintah Yordania menetapkan sikap dengan membuat aturan penutupan bandara, membuat ruang isolasi di rumah sakit, menutup lembaga pendidikan (17). Manifestasi sikap tidak 
dapat langsung dilihat, tetapi hanya dapat langsung ditafsirkan terlebih dahulu dari perilaku yang tertutup (22).

\section{C.Persepsi Dokter Muda dalam Menghadapi COVID-19}

Berdasarkan hasil penelitian, sebanyak $72 \%$ dokter muda mempunyai persepsi yang baik dalam menghadapi COVID-19. Menurut penelitian yang dilakukan di Uni Emirat Arab pada petugas kesehatan, pengetahuan dan persepsi tentang COVID-19 bervariasi di berbagai kategori petugas kesehatan. Studi ini mengungkapkan bahwa petugas kesehatan tidak memiliki pengetahuan yang cukup tentang COVID-19 tetapi menunjukkan persepsi positif tentang pencegahan penularan COVID-19. Lebih dari 33\% petugas kesehatan menggunakan situs web resmi pemerintah sebagai sumber informasi utama tentang COVID-19. Ini menunjukkan bahwa pembaruan terkait COVID-19 yang diposting online oleh pemerintah memiliki implikasi positif untuk meningkatkan pengetahuan petugas kesehatan. Mengandalkan sumber otentik adalah faktor kunci dalam mempercayai informasi yang transparan tentang infeksi COVID-19 yang muncul dan penting untuk kesiapan dan tanggapan petugas kesehatan. Secara umum, sebagian besar partisipan memiliki persepsi positif terhadap pencegahan dan pengendalian COVID-19. Namun, perbedaan diidentifikasi dalam persepsi berbagai kategori petugas kesehatan. Misalnya, hanya setengah (52\%) petugas kesehatan berusia 45-65 tahun percaya bahwa gejala COVID-19 muncul paling cepat 2 hingga 14 hari ( $\mathrm{p}<0,05)$, dan lebih dari seperempat mahasiswa kedokteran berpendapat bahwa makan daging selama wabah tidak aman. Sekitar $20 \%$ petugas kesehatan terkait percaya bahwa vaksin flu cukup untuk pencegahan COVID-19. Akhirnya, sebagian besar petugas kesehatan sangat setuju bahwa menjaga aktivitas kebersihan, melaporkan riwayat perjalanan terkini ketika ada orang sakit, dan membersihkan peralatan yang digunakan di pasar basah sangat dianjurkan (9).

Epidemi dan pandemi adalah fenomena periodik. Orang-orang di masyarakat menghadapi beberapa tantangan selama periode tersebut. Kurangnya kesadaran sering kali mengarah pada sikap tidak peduli, yang dapat mempengaruhi kesiapan untuk menghadapi tantangan ini. Dampak dari epidemi dan pandemi ini sering kali sangat kuat, yang dapat mempengaruhi kesehatan mental populasi tertentu. Ketakutan dan kecemasan terkait epidemi dan pandemi juga mempengaruhi perilaku masyarakat (23). Hal ini terbukti dari masih banyak dokter muda menganggap media terlalu melebih-lebihkan kasus COVID-19 (53,3\%), masih terpengaruh 
dengan postingan media sosial (54,7\%), terpengaruh dengan perbincangan Pandemi Virus Corona di Koran dan kanal berita (50,7\%) dan 34,7 \% menganggap anda virus COVID-19 adalah senjata biologi.

Dalam penelitian yang dilakukan di India, ditemukan sekitar $28 \%$ orang melaporkan kesulitan tidur dan lebih dari dua pertiga responden melaporkan diri mereka khawatir setelah melihat postingan tentang pandemi COVID-19 di berbagai platform media sosial dan sekitar 46\% peserta melaporkan kekhawatiran mereka terkait pembahasan pandemi COVID19 di saluran berita dan media cetak. Hal ini menunjukkan bahwa sebagian besar responden dalam survei, meskipun memiliki kesadaran yang memadai tentang infeksi virus corona, sebagian besar dipengaruhi oleh informasi media. Media memengaruhi kesehatan mental dan menambah tingkat kecemasan. Pandemi flu babi tahun 2009-2010, yang mengakibatkan tingginya angka kematian di seluruh dunia, juga menarik perhatian media global dan menimbulkan kecemasan di antara publik secara signifikan. Panic buying sering terlihat selama pandemi, yang menyebabkan habisnya sumber daya. Laporan media tentang kekurangan sumber daya dan bahan pokok sehari-hari semakin meningkatkan panic buying . Dalam penelitian ini juga, perilaku tidak baik seperti sering (marah, gelisah, khawatir) ada dalam seper-enam reponden. Demikian pula, dua pertiga peserta merasa perlu untuk membicarakan kekhawatiran mereka terkait pandemi COVID-19 dengan seseorang. Di saat yang sama, media elektronik dan cetak, serta media sosial terus membahas status pandemi. Akibatnya,orang tidak mampu mengatasi dan perasaan emosional kelelahan. Lebih dari tiga perempat peserta merasa membutuhkan bantuan untuk kesehatan mental mereka. Dalam situasi ini, mempertimbangkan konsultasi kesehatan mental secara online mungkin bisa dipertimbangkan (23).

\section{KESIMPULAN}

1. Sebagian besar dokter muda mempunyai pengetahuan yang baik dalam mengahadapi pandemi COVID-19

2. Sebagian besar dokter muda mempunyai sikap yang baik dalam menghadapi pandemi COVID-19

3. Sebagian persepsi dokter muda sudah baik dalam menghadapi pandemi COVID-19

\section{REFERENSI}

1. Kementerian Kesehatan RI. Tentang Novel Coronavirus. Available from: 
https:/www.kemkes.go.id/download.php?file=download/info-terkini/COVID-

19/TENTANG NOVEL CORONAVIRUS.pdf

2. WHO. Coronavirus [Internet]. 2020. Available from: https://www.who.int/healthtopics/coronavirus\#tab=tab_1

3. WHO. Coronavirus disease 2019 (COVID-19) Situation Report - 64 [Internet]. Available from: https://www.who.int/docs/default-source/coronaviruse/situation-reports/20200324sitrep-64-covid-19.pdf?sfvrsn=723b221e_2

4. WHO. Coronavirus disease (COVID-19) Situation Report - 178 [Internet]. WHO. 2020. Available from: https://www.who.int/docs/default-source/coronaviruse/situationreports/20200716-covid-19-sitrep-178.pdf?sfvrsn=28ee165b_2

5. Handayani D, Hadi DR, Isbaniah F, Burhan E, Agustin H. Penyakit Virus Corona 2019. J Respirologi Indones. 2020;40(2):120-30.

6. Kementerian Kesehatan RI. Perkembagan Kasus Covid-19 Kumulatif Di Indonesia [Internet]. Jakarta: Kementerian Kesehatan Republik Indonesia; 2020. Available from: http://pusatkrisis.kemkes.go.id/infografis-covid-19-indonesia-16-juli-2020-1600-wib

7. Halik MN. Tanggung jawab dokter muda terhadap pasien dalam memberikan pelayanan kesehatan skripsi. UNiversitas Islam Negeri Alauddin Makassar; 2017.

8. Saqlain M, Munir MM, Rehman SU, Gulzar A, Naz S, Ahmed Z, et al. Knowledge, attitude, practice and perceived barriers among healthcare workers regarding COVID-19: a cross-sectional survey from Pakistan. J Hosp Infect [Internet]. 2020;105(3):419-23. Available from: https://doi.org/10.1016/j.jhin.2020.05.007

9. Bhagavathula A, Aldhaleei WA, Rahmani JR, Mahabadi MA, Bandari DK. Novel Coronavirus (COVID-19) Knowledge and Perceptions: A Survey of Healthcare Workers. JMIR public Heal Surveill [Internet]. 2020; Available from: http://www.ncbi.nlm.nih.gov/pubmed/32320381

10. Doremalen N Van, Bushmaker T, Morris D., Holbrook M., Gamble A, Wiliamson B., et al. Aerosol and Surface Stability of SARS-CoV-2 as Compared with SARSCoV-1. N Engl J Med. 2020;382(1):1564-7.

11. Peng Y, Pei C, Zheng Y, Wang J, Zhang K, Zheng Z, et al. Knowledge, Attitude and Practice Associated with COVID-19 among University Students: a Cross-Sectional Survey in China. Res Sq. 2020; 
12. Salman M, Mustafa ZU, Asif N, Zaidi HA, Hussain K, Shehzadi N, et al. Knowledge, attitude and preventive practices related to COVID-19: a cross-sectional study in two Pakistani university populations. Drugs Ther Perspect. 2020;36:319-25.

13. Wadood MA, Mamun A, Rafi MA, Islam M kamrul, Mohd S, Lee LL, et al. Knowledge, attitude, practice and perception regarding COVID-19 among students in Bangladesh: Survey in Rajshahi Universit. MedRxiv. 2020;

14. Agarwal V, Gupta L, Davalbhakta S, Misra D, Agarwal V, Goel A. Undergraduate medical students in India are underprepared to be the young-taskforce against Covid-19 amid prevalent fears. MedRxiv. 2020;

15. Baloran ET. Knowledge, Attitudes, Anxiety, and Coping Strategies of Students during COVID-19 Pandemic. J Lost Trauma. 2020;25(8).

16. B S, Sudono, Sari D, Farida E, Nurindah R, Adisetyani Y, et al. Standar pencegahan dan pengendalian infeksi pelayanan kesehatan gigi dan mulut di fasilitas pelayanan kesehatan [Internet]. Kementrian kesehatan RI; 2012. Available from: http://pdgi.or.id/wpcontent/uploads/2015/04/PPIGilut. pdf

17. Alzoubi H, Alnawaiseh N, Asma'a Al-Mnayyis, Mohammad Abu- Lubad AA, AlShagahin H. COVID-19 - Knowledge, Attitude and Practice among Medical and NonMedical University Students in Jordan. J Pure Appl Microbiol. 2020;14(1):17-24.

18. Winanti PS, Mas'udi W. Tata Kelola Penanganan Covid 19 di Indonesia. 1st ed. Yogyakarta: UGM Press; 2020. 398 p.

19. Notoatmodjo S. Pendidikan dan Perilaku Kesehatan. Jakarta: PT Rineka Cipta; 2003.

20. Roy D, Tripathy S, Kar SK, Sharma N, Sudhir Kumar Verma VK. Study of knowledge, attitude, anxiety \& perceived mental healthcare need in Indian population during COVID19 pandemic. Asian J Psychiatr. 2020;51.

21. Ssebuufu R, Sikakulya F, Simon Mambo Binezero LW, Nganza SK, Ibrahim B, Kyamanywa P. Awareness, knowledge, attitude and practice towards measures for prevention of the spread of COVID-19 in the Ugandans: A nationwide online crosssectional Survey. MedRxiv. 2020;

22. Sukesih S, Usman U, Budi S, Sari DNA. PENGETAHUAN DAN SIKAP MAHASISWA KESEHATAN TENTANG PENCEGAHAN COVID-19 DI INDONESIA. J Ilmu Keperawatan dan Kebidanan. 2020;11(2). 
23. Roy D, Tripathy S, Kar SK, Sharma N, Verma SK, Kaushal V. Study of knowledge, attitude, anxiety \& perceived mental healthcare need in Indian population during COVID19 pandemic. Asian J Psychiatr [Internet]. 2020;51(April):102083. Available from: https://doi.org/10.1016/j.ajp.2020.102083 